Kulathunga L.C.M.K., Wanigasekara W.A.D.K.J. \& Mendis M.O.S. Wayamba Journal Management 12 (2)

\title{
Effect of Job Design on Task Performance of Engineers of Public Utility Sector Organizations in North Western Province, Sri Lanka
}

\author{
L.C.M.K. Kulathunga ${ }^{1}$, W.A.D.K.J. Wanigasekara ${ }^{2} \&$ M.O.S. \\ Mendis $^{3}$ \\ ${ }^{1}$ Faculty of Business Studies \& Finance \\ Wayamba University of Sri Lanka \\ SRI LANKA \\ ${ }^{2,3}$ Department of Accountancy \\ Faculty of Business Studies \& Finance \\ Wayamba University of Sri Lanka \\ SRI LANKA
}

\author{
malikakulathunga@yahoo.com ${ }^{1}$, kaushalya@wyb.ac.lk², \\ oshanimendis33@gmail.com ${ }^{3}$
}

\begin{abstract}
This study was designed to identify the influence of job design factors on the task performance of project engineers employed in public utility sector organizations in the North Western Province of Sri Lanka. Skill variety, task identity, task significance, autonomy and job feedback factors are considered as independent variables to measure the job design. Research carried out using 113 project engineers in public utility sector organizations in North-Western Province revealed that skill variety, task identity, task significance, autonomy and job feedback influence on employee task performance in a project context. The analysis was done by applying correlation analysis and multiple regression analysis. It was illustrated a significant moderate relationship between independent variables and dependent variables. Results of the regression analysis indicated a significant positive impact of independent variables on dependent variables. Further, the results revealed that job autonomy is the highest contributing factor while task identity, job feedback, task significance, and skill variety contribute to the task performance of the project engineers, respectively. Therefore, it is concluded that the job design enhance task performance of project engineers in public utility sector organizations in the North Western Province of Sri Lanka.
\end{abstract}

Keywords-: Job Design, Sri Lanka, Task Performance, Utility Sector 


\section{INTRODUCTION}

Human Resource is the backbone of an organization. It has the most significant effect on the organization compared with other resources like machines, materials, land, etc. The success of the effective physical resources of an organization cannot be achieved without human resources. In the organizational context, the effectiveness of human resources depends on designing the job according to human capability and characteristics. Job design is the most important function of human resources management. (Boxall et al. 2008) It indicates the designing of contexts, methods and functions of the job. Employee task performance directly influences goal achievements and performance towards the organization. According to the past research, certain factors individually and collectively affect the task performance of the employees.

Organizations have been focused on issues such as employee satisfaction, retention, turnover, brain drain, job enrichment, job enlargement, work design, performance evaluation, and other human resource tasks for the past two decades in order to retain people loyal to the company. (Khalid \& Nawab, 2018). Thereby, the need of human resource management becomes more pronounced and obligatory, as human resources cannot be replicated. It is the managerial factor that makes the difference in achieving organizational success.
Many people believe that income is the most significant motivator at work. However, studies show that a different factor, job design, has a significant impact on worker performance. The design of a work has a significant impact on employee motivation, job satisfaction, commitment to an organization, absenteeism, and turnover. In the organizational context, the effectiveness of human resources depends on designing the job according to humans' capabilities and characteristics. (Boxall et al. 2008) The employee performs his or her task, duties and responsibilities. The achievement of goals and objectives of the organization is assessed by the performance of its resource like a human.

Zhu et al. (2007) highlighted that the initial development of the human resource management concept is based on the effective utilization of people and treating them as resources leading to the realization of business strategies and organizational objectives. Employee performance is the most decisive component in each organization because the accomplishment of organizational objectives depends on the performance of its employees. Accordingly, many corporate-level managers evaluate the employee performance of each staff member annual or quarterly basis to identify the areas for performance improvement. 


\subsection{Research Problem}

National Water Supply \& Drainage Board (NWSDB) has its beginning as a sub-department under the Public Works Department (PWD) for Water Supply and Drainage. The NWSDB presently functions under the Ministry of Water Supply. During the last 45 years, the organization has considerably expanded its scope of activities. The numbers of employees have increased from one thousand to ten thousand from 1975 to 2020 . NWSDB has the most qualified and experienced staff in the water supply and sewerage sector in Sri Lanka.

The electricity sector in Sri Lanka is governed by the Sri Lanka Electricity Act, No. 20 of 2009. Ceylon Electricity Board (CEB), established by the CEB Act No. 17 of 1969 (as amended), is under a legal obligation to develop and maintain an efficient, coordinated and economic system of electricity supply in accordance with any licenses issued. The CEB has to develop and maintain an efficient and coordinated economic system of electricity supply to the country as well as generate or acquire supplies of electricity.

In the 1950s, the country's main road network was developed and maintained by the PWD. This department was responsible for roads and buildings, water supply \& drainage, and housing, etc. In the mid-1960s, the PWD was responsible only for the development and maintenance of the public roads and buildings. The Road Development Authority (RDA) functions were expanded in 1986, when it became the successor to the Department of Highways. In 1986, the RDA was entrusted with developing and maintaining all classified roads in the country (A, $\mathrm{B}, \mathrm{C}, \mathrm{D}$ and $\mathrm{E}$ class roads) totaling up to approximately $28,000 \mathrm{~km}$ of roads and bridges.

During the last few years, local and foreign-funded projects conducted by NWSDB, CEB and RDA were not completed within the designed time period. Key Performance Indicators (KPI) of the selected organizations show that delays (refer Table 1) in completing the projects affected productivity, performance and economy of the particular organization. Therefore, it is highly influence for overall performance of the organization itself. It is anticipated that job design is engaged for each objective or project. It should generate a synergy effect to exhibit higher performance.

The reports issued by the Department of Project Management and Monitoring (DPMM) (Progress of development projects and programme as at $31^{\text {st }}$ of March, 2019) identified major reasons for delay the funded projects in Sri Lanka.

The figure 1 shows that when considering the issues pertaining to the project implementations, a considerable percentage (38 percent) represents the 
organizational and project monitoring unit issue. These are related to organizational employees' performance, which might be affected by the different human resource managerial aspects, including job design. Therefore, it should take the necessary steps to complete all components within the agreed time frame by effective contract management through proper job design and close supervision of the contractor's performance. In the progress reports of the DPMM unit concluded that performance incommensurate of project staff is a burning issue and it is required to address this issue immediately.

Moreover, there is a general perception among the public that the public sector organizations are inefficient and ineffective in using limited resources, and thereby those organizations constitute a significant burden to the government of Sri Lanka, (Athukorala et al. 2017). The behavioral pattern of the engineers was changed during the past few years, showing that absenteeism, unionized behavior, turnover, etc. Also, criticism was pointed out internally by the top management of public utility sector organization and Project Management unit staff about the antagonistic behaviors of engineers less attention, commitment and involvement role of their work. Some engineers and engineering assistants are not confident about their jobs and tasks; they have not perceived the job autonomy and level of job authority. Therefore, a low degree of job involvement was found during the past within these government utility sector organizations.

Specially, for the success of a project, the project management unit must consider how to ensure that employees are equipped with attributes as responsibility, quality of work, job knowledge, ability, experience, accuracy, judgement and initiative. Therefore, it is significant to carry out the studies to explore the reasons behind such low level of engineers' and engineering assistants' performance, which in turn affects delay in implementations of projects.

There are studies available in the international context to explore the impact of job design on task performance of employees (Humphrey, 2007; Demerouti, 2006; Morgeson, 2005; George \& Zhou, 2001; Tierney \& Farmer, 2002; Oldham \& Cummings, 1996). But, according to the knowledge of the authors, there are no research studies done on the effect of job design on task performance of engineering staff in public utility sector organizations in Sri Lankan context. Therefore, the present study was designed to fill this empirical research gap. Thus, the research problem, which this study addressed, is, "Is there any effect of job design on task performance of engineers of public utility sector organizations in North Western Province in Sri Lanka?'. 
Thus, the answer for this research question is found based on the performance of engineering employees in all levels, who are employing in the public utility sector organizations, such as; NWSDB, CEB and RDA in the North-Western province of Sri Lanka.

\subsection{Research Questions}

Following research questions are formed to be answered through the present study;

1. Does job design impact the task performance of engineers at all levels in public utility sector organizations in the North Western province of Sri Lanka?

2. To what extent does skill variety impact the task performance of engineers of all levels in public utility sector organizations in the NorthWestern province of Sri Lanka?

3. Does the task identity impact the task performance of engineers of all levels in public utility sector organizations in the North Western province of Sri Lanka?

4. Does task significance impact the task performance of engineers of all levels in public utility sector organizations in the North-Western province of Sri Lanka?

5. To what extent does job autonomy impact the task performance of engineers of all levels in public utility sector organizations in the NorthWestern province of Sri Lanka?
6. Does feedback impact on the task performance of engineers of all levels in public utility sector organizations in the North Western province of Sri Lanka?

\subsection{Research Objectives}

The primary objective of this study is to investigate the impact of job design on task performance of engineers.

More specifically following objectives are to be achieved by the study.

1. To identify the impact of job design on task performance of engineers of all levels in public utility sector organizations in North Western Province of Sri Lanka.

2. To determine the impact of skill variety on task performance of engineers of all levels in public utility sector organizations in North Western Province of Sri Lanka.

3. To investigate the impact of task identity on task performance of engineers of all levels in public utility sector organizations in North Western Province of Sri Lanka.

4. To identify the impact of on task significance on task performance of engineers of all levels in public utility sector organizations in North Western Province of Sri Lanka.

5. To find the impact of feedback on task performance of engineers of all levels in public 
utility sector organizations in North Western Province of Sri Lanka.

6. To determine the impact of job autonomy on task performance of engineers of all levels in public utility sector organizations in North Western Province of Sri Lanka.

\subsection{Significance of the Study}

The main purpose of this study is to find the impact of job design on the task performance of the engineers of all levels in the public utility sector organizations. Therefore, more importantly, the findings of the study will be significant to the projects in NWSDB, CEB and RDA, North Western Province in Sri Lanka. Because, these organizations spend massive amount of capital, technology and labor, knowledge, experience and expertise toward the accomplishment of utility infrastructures. Thus, it will be significant to the public utility sector organization as to take necessary action to improve project engineers' task performance in projects.

In addition, this research may be greatly significant to employers, it gives supplementary information and knowledge that can carry out productive task performance. Managers can focus on which factors can affect task performance of employees and help the organization earn a higher level of performance.
Further, the research findings of the present study are beneficial to the projects staff, such as engineers, technical officers, administration staff, etc. They can improve their job performance which can ultimately increase organizational performance.

Moreover, the present research findings will be useful to the project directors, contractors, engineers, and other stakeholders to implement their project activities based on effective job design and achieve the best performance of project engineers.

The rest of the article contains the literature relating to employee performance and job design, methodology, findings and discussion and finally the conclusion.

\section{LITERATURE REVIEW}

\subsection{Task Performance of Employees}

Employee performance is a key factor that contributes directly to the performance of the company. Companies today, with increased competition in the business arena, are keen to boost employee performance in order to enhance their profitability, market reach and brander cognition. Thus, human resource managers and quality managers have put special emphasis on techniques to gauge employee performance and periodically conduct review sessions in order to monitor it. Campbell (1990) 
defined job performance as actions or behaviors relevant to organizational goals, which includes both productive and counterproductive employee behaviors that contribute to or detract from organizational goals. It is introduced Viswesvarn (2000) as the more recent definition of job performance as behavior and outcomes that employees undertake that are contribute to organizational goals. Motowidlo (1993) refers to job performance as the effectiveness of individual behaviors that contribute to organizational objectives and should consist of task performance and contextual performance. Both constructs are influenced by different factors, for instance, jobrelated experience determines task performance while Organ (1988) defined individual's personality type determines contextual performance and term "job performance" may need to redefine to essentially broaden this construct to include non-productivity or extra-role dimensions such as cooperation, helping co-workers and superiors and generalized tendencies toward compliance. Gomez (2007) stated that task performance should be distinguished into quality of work done, quantity of work performed, and interpersonal effectiveness. Therefore, from the above definitions it is clear that task performance is related to the extent to which an employee is able to accomplish the task assigned to him or her and Mawoli (2011) defined by how the accomplished task contributes to the realization of the organizational goal.

\subsection{Job Design}

Job design is an important factor that makes a significant amount of impact on employee performance. The more efficient job design leads to more job satisfaction and good employee's performance. Therefore, employers, departmental head of the organization and the company managers are always looking for the opportunity and alternatives to increase a welldeveloped job design and employee satisfaction because worker performance basically depends on the level of job design and satisfaction on the job. Meanwhile, company's vision, mission, goals, and objectives are also reliant on employee's performance.

Buchanan (1979) found that job design as specifying the contents or methods of any job in such a way that various requirements of the job holder can be effectively satisfied. Ambrose (2013) defined job design as the creation of tasks and work settings for specific tools. Job design focuses on the way that a set of tasks or an entire position is organized (Grant, 2010). Opatha (2009) defines job design as the function of arranging tasks, duties and responsibilities into an organizational unit of work for the purpose of accomplishing the primary goal and objectives of the organization. He further noted there are two categories of elements, i.e. efficiency elements and behavioral 
elements. Efficiency elements include division of labour, standardization and specialization. Behavioral elements include skill variety, task identity, task significance, autonomy and feedback.

The skills, task identity, task significance, autonomy, feedback, job security and compensation are important factors for the motivation of employees as identified by Bassey (2002), Garg \& Rastogi (2005) and Hackman \& Oldham (1976).

\subsection{Job Design and Task Performance of Employees}

The study focuses on the topic that "Impact of Job Design on Employees' Performance in People's Banks of Ampara District" by Ali \& Aroosiya (2010) identified whether the job design shapes the employees' performance. Some of the researchers have analyzed the relationship of job design and employee performance and concluded that there is a strong positive relationship between them. Studied about "Job Design and Employees' Performance with special reference to school teachers in the Kalmunai zone by Ali \& Rehman (2014) studied about "Impact of Job Design on Employee Performance, mediating role of job satisfaction. A study of FMCG's sector in Pakistan" The study measured about the effect of job design on employees' performance while the mediation effect is job satisfaction.
According to Rush (1971), the main purpose of the job design (or redesign) is to increase both employee motivation and productivity. Job design can have a significant effect on motivation. Increased productivity can manifest itself in various forms. Garg \& Rastogi (2005) established body of knowledge supporting the idea that certain jobs and goal setting can enhance the performance. It is experience that well designed jobs can have a positive impact on both employee satisfaction and the quality of performance. Therefore, the study of Garg \& Rastogi (2005) shows that a well-defined job would enhance motivation, satisfaction and performance of the employees.

\subsection{Theoretical Background}

Organizations may apply various types of theoretical approaches for job design. Each one of the approaches indicates different aspects that have to be considered for job design effective. There are two theories about job design; Herzberg's Two-Factor Theory (1966) and Job Characteristics Model (1976).

The Job Characteristics Model is the most appropriate theoretical underpinning for the current study. Therefore, the following section presents the Job Characteristics Model.

\subsubsection{Hackman Characteristics Model}


The job characteristics model was originally developed by Turner and Lawrence and has been revised by Hackman and Lawler. The final version of the job characteristics model, as used in many theoretical reviews, has been done by Hackman and Oldham (1976). They summarized the job characteristics into five core dimensions as illustrated in Figure 2.

The Job Characteristics Model asserted that individual performance can be enhanced when employees perceive that their job entails the above mentioned five main characteristics. The design and characteristics of job are important for an organization because they provide significant influence on employees' intrinsic motivation and would lead to a higher level of job performance among employees as per the studies of George \& Zhou (2001) Tierney \& Farmer (2002) and Demerouti (2006). Whereas past researchers have proposed other dimensions of job characteristics such as autonomy, feedback, skill variety, task significance and task identity as dimensions of job factors that significantly affect employee performance. Oldham and Cummings (1996) and Morgeson (2005) found out jobs that are designed with high complexity characterized by high levels of autonomy, skill variety, identity, significance and feedback can have a positive impact on employees' performance.

\section{METHODS}

\subsection{Population and Sample}

The population of this study is 160 project engineers in NWSDB, CEB and RDA of North Western Province in Sri Lanka. The researchers had to limit only to the North Western Province in Sri Lanka due to the data collection difficulties aroused because of Covid - 19 pandemic situations. The sample was selected using systematic random sampling. According to the Morgan Sample Criteria, 113 project engineers were selected.

\subsection{Conceptual Framework}

The conceptual framework is presented in the figure 03 of the appendix.

\subsection{Hypotheses}

According to Benjamin (2012) the theory behind providing skill variety in job design is that it will reduce boredom, thereby increasing job satisfaction and motivation. Similarly, Ghosh (2015), Krasman (2012), Sulea et al. (2012) and Davis (2005) reported that a job that allows employees to engage in different activities and to use various skills and talents will result in a positive attitude and behavioural outcomes at work. Feldman, \& Pentland, (2003) stated that skill variety is considered as the number of various task elements that are necessary for job fulfilment. Task variety communicates clarity of knowledge. According to the 
literature of careers, employees at the start of their careers make attempts to discover tasks from which they attain or achieve their goals (Feldman \& Thomas, 2012).

Accordingly, the first hypothesis of the study is formulated as;

$\mathbf{H}_{1-}$ There is a significant effect of skill variety on task performance of engineers of all levels in public utility sector organizations in the North Western Province of Sri Lanka.

Task identity is the degree to which the job requires completion of a whole and identifiable piece of work that is doing the job from beginning to end with a visible outcome. Task wholeness increases the employees", sense of responsibility, ownership and control over work activities (Fiedler, 1997). As task identity increases, employees are able to evaluate themselves in terms of the quality of work done. Uruthirapathy and Grant (2015) found that employees who have enlarged jobs and are involved in more tasks in their workflow are more likely to perform better than those who are not undergoing such work conditions. Task identity was considered a source of motivation for the employees, which then leads to improved performance (Choge et al. 2014).

Based on the literature discussed above, the second hypothesis of the study is formulated as;
$\mathbf{H}_{2}$ - There is a significant influence of task identity on task performance of engineers of all levels in public utility sector organizations in the North Western Province of Sri Lanka.

Task significance is an integral part of job characteristics that contribute to employee performance. Hirschfeld et al. (2002) proved that high performance increases if the results of the specific efforts are seen to be highly important and relatively has an impact on others. A high level of task significance is relative to a low level of absence from work (Rentsch \& Steel, 2003) and a high level of individual work satisfaction (Orpen, 1979). As for the public servants, when they recognize that their work has an important impact on the organization's ability to achieve its mission, vision, and established business goals, they will develop feelings of social impact and social worth, particularly in the context of their present employment. In essence, public servants would consider that their jobs worthwhile if they believe that their role would make a positive impact on others in the respective department they are attached to as well as on the community at large (Hauff \& Richter, 2015; Hassan, 2014; Krasman, 2012).

Thus, the third hypothesis can be formulated as;

$\mathbf{H}_{3}$ - There is a significant impact of task significance in task performance of engineers of all 
levels in public utility sector organizations in the North Western Province of Sri Lanka.

Job autonomy is defined as the degree to which the job provides substantial freedom, independence, and discretion to the individual in scheduling work and in determining the procedures to be used in carrying it out. Job autonomy is one of several core job design characteristics developed by Hackman \& Oldham (1975).

Gallantly and Irving (2001) found a positive effect of perceived autonomy on contextual performance. Managers who report greater autonomy in their work have a better performance than managers who report lower autonomy. Claessens et al. (2004) found that perceived autonomy in time was positively related to job performance and job satisfaction and negatively to work strain. According to Langfred \& Moye (2004), job autonomy enhances job performance because they perceive themselves as capable and more resourceful in performing the task. Psychologically, employee will more motivate to do the best and leads to higher performance. Therefore, a positive linkage can be hypothesized between job autonomy and job performance

$\mathbf{H}_{4}$ - There is a significant impact of autonomy on task performance of engineers of all levels in public utility sector organizations in North Western Province of Sri Lanka.
Feedback refers to the degree to which carrying out the work activities required by the job results in the individual's obtaining direct and clear information about the effectiveness of his or her performance (Garg \& Rastogi, 2006 cited in Ali \& Aroosiya, 2010). In their study Morris and Venkatesh (2010) revealed that feedback has a positive relationship with job performance. Bacha (2014), Ghosh et al. (2015) and Krasman (2012) reported in their findings that employees who obtained feedback from the work they have done are more likely to demonstrate positive attitude and behavior at work. Thus, the fifth hypothesis of the study is;

$\mathbf{H}_{5^{-}}$- There is a significant impact of feedback on task performance of engineers of all levels in public utility sector organizations in North Western Province of Sri Lanka.

The design and characteristics of job are important for organization because it provides significant influence on employees' intrinsic motivation and would lead to higher level of job performance among employees as per the studies of George \& Zhou (2001); Tierney \& Farmer, 2002 and Demerouti (2006). Whereas previous studies have proposed other dimensions of job characteristics such as autonomy, feedback, skill variety, task significance and task identity as dimensions of job factors that significantly affect employee performance (Oldham \& Cummings, 1996; Tierney \& Farmer, 2002). In accordance with 
the literature, the last hypothesis of the study is formulated as;

$\mathbf{H}_{\mathbf{6}}$ - There is a significant effect of job design on the task performance of engineers of all levels in public utility sector organizations in the North Western Province of Sri Lanka.

\subsection{Research Instrument and Method of Data Collection}

A structured questionnaire, which was based on the previous literature was used for the data collection. The questionnaire contained 29 numbers of questions except the questions related to the respondents' profile data. All other questions were put forwarded in "Likert Scale".

There were 5 questions related with demographic factors of the respondents, 4 questions each for Skill verity (differentiation of skills, level of skill use, variety of skills, number of skills), task identity (task involvement, task arrangement, level of task, task completion) and task significance related indicators (task significance, impact of task), 9 job autonomy related questions (work scheduling autonomy, planning, decision making autonomy, work method autonomy), 3 feedback related questions (effectiveness of performance, feedback on performance and information) and 5 task performance questions (timeliness, quality of work, quantity of work, less supervisory intervention and interpersonal cooperation) in the questionnaire. The questionnaire was distributed among project engineers of NWSDB, CEB and RDA office within the North Western Province through emails. The relevant project directors were informed about the survey and the purpose of the study. Then the data were collected via email, post and by hand.

\subsection{Results of Reliability Assessment}

The Cronbach's alpha was calculated to assess the reliability. Cronbach's alpha value indicates how far established questions are consistent as group and relativeness to the established variable. Accordingly, all the variables have a very good reliability (skill variety $=0.924$, task identity $=0.901$, task significance $=0.881$, job autonomy $=0.850$, feedback $=0.950$, employee performance $=0.914$ and job design $=0.708$ ). According to Zikmund et al. (2010) all the variables have very good reliability except job design, which has good reliability.

\subsection{Method of Data Analysis}

The reliability analysis was done to ensure the internal consistency of all components in the questionnaire Assumptions for regression analysis were also executed before analyzing the data. The descriptive statistics were used to explain the behaviour of data. Regression analysis and correlation analysis 
were undertaken to analyze the data and to test the hypotheses.

\section{RESULTS AND DISCUSSION}

This proceeded with data presentation and analysis of obtained views from the questionnaire.

\subsection{Results Demographics Analysis}

The demographic analysis revealed that Gender distribution shows $77.9 \%$ percentage of males and $22.1 \%$ percentage of females exists in the considered sample of project engineers. It shows that, male employment is much higher than female employment in the construction project sector in Sri Lanka. The age distribution shows that $13.3 \%$ are below 30 years ages and $53.1 \%$ are in 31 years to 40 years. $22.1 \%$ is in the age category of 41 years to 50 years. $11.5 \%$ are in the age category of 51 years to 60 years. The educational background of the engineers selected for the study shows that the majority of the engineers have postgraduate qualifications $(61.1 \%)$, indicating an excellent educational background among the project engineers in Sri Lanka.

\subsection{Results of Correlation Analysis}

The table 2 indicates that the moderate positive relationship between skill variety and task performance of project engineers coefficient of correlation is 0.591 , which is statistically significant $(\mathrm{P}<0.05)$. Further, a moderate positive relationship between task identity and task performance of project engineers coefficient of correlation is 0.473 , which is also statistically significant $(\mathrm{P}<0.05)$. The correlation coefficient between task significance and task performance is 0.403 , which is statistically significant and a higher positive relationship exists $(\mathrm{P}<0.05)$. Moreover, the relationship between job autonomy and task performance is also moderate, and the correlation coefficient value is 0.525 , which is statistically significant. Furthermore, there is a moderate positive relationship between feedback, and task performance of project engineers correlation coefficient is 0.529 , which is statistically significant.

According to the correlation analysis, it is revealed that skill verity,task identity, task significance, job autonomy and feedback have moderate positive relationship with task performance of project engineers and correlation is statistically significant, indicating that there is a significant relationship between job design and task performance of project engineers in public utility sector organizations in North Western province of Sri Lanka.

\subsection{Results of Regression Assumption}


It was found that all the variables satisfied the normality criteria, and it was assessed through the histogram analysis. Further, collinearity diagnostic was done using statistics of tolerance and Variable Inflation Factor (VIF) to identify the multicollinearity problem. According to the results of the statistics, it was ensured that there were no multicollinearity symptoms in the data set. Moreover, heteroscedasticity and linearity of data test were measured by examining the actual standardized residual values of a dependent variable against the predicted residual values of the dependent variable, classical assumption test in the regression model. Based on the scatterplot output, it can be indicated that the regression model has no heteroscedasticity and linearity problems. Thus, all of the tested normality assumptions in the study were at a satisfactory level.

\subsection{Results of Regression Analysis}

The present study used multiple regression analysis to analyze the impact of skill verity, task identity, task significance, feedback and job autonomy on task performance of project engineers in public utility sector organizations in North Western province in Sri Lanka.
The table 3 presents the results of the regression analysis of the study. The regression results show that all the independent variables have a significant positive impact on employee performance of project engineers in public utility sector organizations in North Western province in Sri Lanka.

The lowest contribution according to the beta coefficient, skill variety is identified $(\mathrm{B}=0.073)$. Hence, the predicted skill variety variable relatively influences to task performance. On the other hand, skill variety explains the variation in skills at the lowest contributing level compared with the other four predictors: task identify, task significance, feedback, and job autonomy.

Further, the coefficient of determination $\left(\mathrm{R}^{2}\right)$ reveals a high explanation power on task performance by the study's independent variables. The study's independent variables explain 83.8 percent of variance of the task performance of project engineers of public sector utility sector organizations in North Western province of Sri Lanka.

\subsection{Hypotheses Testing}

According to the results of the regression analysis, the hypotheses of the study can be tested.

The hypothesis 1 of the study $\left(\mathrm{H}_{1}\right.$. There is a significant effect of skill variety on task performance of engineers of all levels in public 
utility sector organizations in North Western Province of Sri Lanka) can be accepted, since the regression coefficient of skill variety was 0.073 , which was significant $(\mathrm{p}=$ $0.021)$. The regression coefficient relating to task identity was 0.525 with $\mathrm{p}$-value of 0.000 . Therefore, $\mathrm{H}_{2}$, i.e. there is a significant influence of task identity on task performance of engineers of all levels in public utility sector organizations in North Western Province of Sri Lanka, can also be accepted. Further, it was found that the regression coefficient of task significance was 0.378 , which was significant $(\mathrm{p}=0.000)$. Hence the third hypothesis of the study $\left(\mathrm{H}_{3}-\right.$ There is a significant impact of task significance on task performance of engineers of all levels in public utility sector organizations in North Western Province of Sri Lanka) was accepted. Moreover, the regression coefficient of job autonomy was found as 0.795 with $p$-value of 0.000. Thus, $\mathrm{H}_{4-}$ There is a significant impact of autonomy on task performance of engineers of all levels in public utility sector organizations in North Western Province of Sri Lanka can be accepted. Furthermore, it was found that the fifth hypothesis of the study $\left(\mathrm{H}_{5}\right.$ - There is a significant impact of feedback on task performance of engineers of all levels in public utility sector organizations in North Western Province of Sri Lanka) can also be accepted since there was a regression coefficient of feedback of 0.486 with a p-value of 0.000 .
Finally, the last hypothesis of the study, i.e. $\mathrm{H}_{6}$ - There is a significant effect of job design on task performance of engineers of all levels in public utility sector organizations in North Western Province of Sri Lanka can be accepted since all the independent variables representing job design have shown a significant positive impact on task performance of engineers of all levels in public utility sector organizations in North Western Province of Sri Lanka.

\section{CONCLUSION}

This study was designed to investigate the impact of job design on the task performance of the project engineers in all levels of the public utility sector organizations in the North-Western province of Sri Lanka.

The study used a structured questionnaire with excellent reliability to collect the views of 113 engineers at all levels in the public utility sector organizations in the North-Western province of Sri Lanka. The majority of the respondents were males, and the majority was in the matured level of their age. Further, it was revealed that the majority of the engineers in public utility sector organizations in the North-Western province of Sri Lanka have good academic qualifications.

There are moderate positive relationships existing in job design, skill verity, task identity, task significance, job autonomy 
feedback on task performance of project engineers, which are statistically significant. It indicates that project engineers' task performance is moderately related to skill verity, task identity, task significance, job autonomy, and feedback in engineers in public utility sector organizations in North Western Province, Sri Lanka.

Further, according to the regression analysis, job autonomy is the strongest variable that influences task performance. This means that task performance strongly depends on job autonomy approach. It emphasized that project engineers believe that job autonomy is often dictated by an organization's structure and culture. The traditional and bureaucratic organizations often have little autonomy, but newer, more organic structures rely on autonomy, empowerment, and participation to succeed. Engineers' job autonomy is believed to have minimized some of the relational barriers between superiors and subordinates. Therefore, autonomy may improve workplace functions through their ideas and suggestions and foster relationships with a greater degree of trust between management and employees.

The second strongest variable is the task identity. This means task identity strongly contributes to increasing task performance in engineers of the public utility sector organization in North Western Province. When the task and role of employees have been well defined, responsibilities have been clearly stated, required training provided, involved in decision-making, and wellauthorized project engineers perform their duties in an excellent manner. Considering the completion of the project on time within the allocated budget frame, it is essential to have engineers' job involvement and the ability to engineers to do an entire piece of work from the beginning to end and giving engineers the chance to completely finish the pieces of work that they begin.

The third strongest variable is feedback. Accordingly, it is emphasized that feedback strongly influences task performance. It implies that job feedback is the supported component on task performance of engineers in projects of public utility sector organizations in North Western Province. Effective feedback can reduce employee mistakes, enhance performance and increase efficiency within the workplace. Therefore, it is critical that managers who are seeking to increase productivity and reduce costs ensure to provide effective feedback to their employees. In general, job feedback in the project is effective within and outside the organization.

The fourth strongest predictor variable is task significance. The results of engineers' work are likely to significantly affect other people's lives within the organization. The job itself is very significant and important in the broader scheme of things. The job has a large impact 
on people outside the organization, and work performed on the job has a significant impact on people outside the organization.

Skill variety is the lowest contributing variable of this model on task performance. Project engineers should have qualified for high technical practices and be aware of updated technology with different skills. Skills in designing, planning, procurement, communication and construction are essential for project settings. The skills in usage of technology are common in most projects, specially in multinational projects. Because these funded projects are constructed by foreign contractors and they are aware of different skills with the modern techniques in globally. Therefore, it is obvious that project engineers should have such skills. Hence, project engineers believe that skill verity is not the most impactful factor for task performance compared with other factors.

The findings of the study are consistent with previous research findings (Demerouti, 2006; Morgeson, 2005; Tierney \& Farmer, 2002; George \& Zhou, 2001; Oldham \& Cummings, 1996).

Accordingly, all the hypotheses of the study were accepted. It was concluded that skill verity, task identity, task significance, job autonomy and feedback factors considerably affect the performance of project engineers in public utility sector organizations in North Western Province in Sri Lanka. Moreover, the model is good enough to explain the variances in task performance of engineers in public utility sector organizations in North Western Province in Sri Lanka. 


\section{APPENDIX}

Table 1: Delays in Projects of Public Utility Sector Organizations in North Western Province from 2015 to 2019

\begin{tabular}{|l|l|l|l|}
\hline Project & $\begin{array}{l}\text { Year of } \\
\text { Commencement }\end{array}$ & $\begin{array}{l}\text { Year of } \\
\text { Completion } \\
\text { (Projected) }\end{array}$ & $\begin{array}{l}\text { Year of } \\
\text { Completion } \\
\text { (Actual) }\end{array}$ \\
\hline $\begin{array}{l}\text { Dry Zone urban water and } \\
\text { sanitation project } \\
\text { (Chilaw/Puttalam) }\end{array}$ & June 2009 & $\begin{array}{l}\text { December } \\
2017\end{array}$ & March 2019 \\
\hline $\begin{array}{l}\text { Greater Kurunegala Water } \\
\text { Supply and Sewerage } \\
\text { Project }\end{array}$ & February 2014 & $\begin{array}{l}\text { November } \\
2017\end{array}$ & $\begin{array}{l}\text { October } \\
2018\end{array}$ \\
\hline $\begin{array}{l}\text { Deduru Oya Water Supply } \\
\text { Project }\end{array}$ & December 2016 & March 2019 & $\begin{array}{l}\text { Ongoing } \\
(80 \%)\end{array}$ \\
\hline $\begin{array}{l}\text { Galagedara - } \\
\text { Mawathagama Water } \\
\text { Supply Project }\end{array}$ & 2014 & 2016 & $\begin{array}{l}\text { Ongoing } \\
(94 \%)\end{array}$ \\
\hline $\begin{array}{l}\text { Flyover at Polgahawela } \\
\text { Integrated Road } \\
\text { Investment Programme }\end{array}$ & April 2016 & $\begin{array}{l}\text { December } \\
2018\end{array}$ & March 2019 \\
\hline $\begin{array}{l}\text { Green Power } \\
\text { Development and Energy } \\
\text { Efficiency Improvement - } \\
\text { Puttalam }\end{array}$ & March 2016 & 2018 & $\begin{array}{l}\text { Ongoing } \\
(95 \%)\end{array}$ \\
\hline
\end{tabular}

Source: Progress Development Project and Programme as at $31^{\text {st }}$ March 2019, Department of Project Management and Monitoring

Table 2: The Results of Correlation Analysis

\begin{tabular}{|l|l|l|l|l|l|l|l|}
\hline Variable & & TP & JA & FB & TS & TI & SV \\
\hline \multirow{2}{*}{ TP } & $\begin{array}{l}\text { Pearson } \\
\text { Correlation }\end{array}$ & 1 & $.525^{* *}$ & $.529^{* *}$ & $.403^{* *}$ & $.473^{* *}$ & $.591^{* *}$ \\
\cline { 2 - 8 } & Sig. value & & .000 & .000 & .000 & .000 & .000 \\
\hline \multirow{2}{*}{ JA } & $\begin{array}{l}\text { Pearson } \\
\text { Correlation }\end{array}$ & $.525^{* *}$ & 1 & .129 & .072 & .096 & $.351^{* *}$ \\
\cline { 2 - 8 } & Sig. value & .000 & & .175 & .446 & .310 & .000 \\
\hline \multirow{2}{*}{ FB } & $\begin{array}{l}\text { Pearson } \\
\text { Correlation }\end{array}$ & $.529^{* *}$ & .129 & 1 & $.251^{* *}$ & $.235^{*}$ & $.510^{* *}$ \\
\cline { 2 - 8 } & Sig. value & .000 & .175 & & .007 & .012 & .000 \\
\hline \multirow{2}{*}{ TI } & $\begin{array}{l}\text { Pearson } \\
\text { Correlation }\end{array}$ & $.403^{* *}$ & .072 & $.251^{* *}$ & 1 & $.590^{* *}$ & $.383^{* *}$ \\
\cline { 2 - 9 } & Sig. value & .000 & .446 & .007 & & .000 & .000 \\
\hline \multirow{2}{*}{ SV } & $\begin{array}{l}\text { Pearson } \\
\text { Correlation }\end{array}$ & $.473^{* *}$ & .096 & $.235^{*}$ & $.590^{* *}$ & 1 & $.194^{*}$ \\
\cline { 2 - 8 } & Sig. value & .000 & .310 & .012 & .000 & & .039 \\
\cline { 2 - 8 } & $\begin{array}{l}\text { Pearson } \\
\text { Correlation }\end{array}$ & $.591^{* *}$ & $.351^{* *}$ & $.510^{* *}$ & $.383^{* *}$ & $.194^{*}$ & 1 \\
\cline { 2 - 8 } & Sig. value & .000 & .000 & .000 & .000 & .039 & \\
\hline
\end{tabular}


Kulathunga L.C.M.K., Wanigasekara W.A.D.K.J., Mendis M.O.S.,

Wayamba Journal Management 12 (2)

Source: Compiled by authors

(TP-Task Performance, JA-Job Autonomy, FB-Feedback, TS-Task Significance, TI-

Task Identity, SV-Skill Verity)

Table 3: Results of Regression Analysis

\begin{tabular}{|c|c|c|c|c|c|}
\hline \multicolumn{6}{|l|}{ Coefficients } \\
\hline \multirow{2}{*}{ Model } & \multicolumn{2}{|c|}{$\begin{array}{l}\text { Unstandardized } \\
\text { Coefficients }\end{array}$} & $\begin{array}{l}\text { Standardized } \\
\text { Coefficients }\end{array}$ & \multirow[t]{2}{*}{$\mathrm{t}$} & \multirow[t]{2}{*}{ Sig. } \\
\hline & B & $\begin{array}{l}\text { Standard } \\
\text {. Error }\end{array}$ & Beta & & \\
\hline Constant & -1.922 & 0.398 & & -2.103 & 0.000 \\
\hline SV & 0.073 & 0.053 & 0.071 & 1.378 & 0.021 \\
\hline TI & 0.525 & 0.041 & 0.736 & 12.895 & 0.000 \\
\hline TS & 0.378 & 0.083 & 0.255 & -4.566 & 0.000 \\
\hline FB & 0.486 & 0.038 & 0.683 & 12.763 & 0.000 \\
\hline JA & 0.795 & 0.092 & 0.360 & 8.602 & 0.000 \\
\hline $\mathrm{R}^{2}$ & \multicolumn{5}{|l|}{0.838} \\
\hline Adjusted $\mathrm{R}^{2}$ & \multicolumn{5}{|c|}{0.830} \\
\hline \multicolumn{6}{|c|}{$\begin{array}{l}\text { a. Predictors: (Constant), Skil verity, task identity, task significance, job autonomy, } \\
\text { feedback }\end{array}$} \\
\hline \multicolumn{6}{|c|}{ a. Dependent Variable: Task Performance } \\
\hline
\end{tabular}

Source: Compiled by the authors

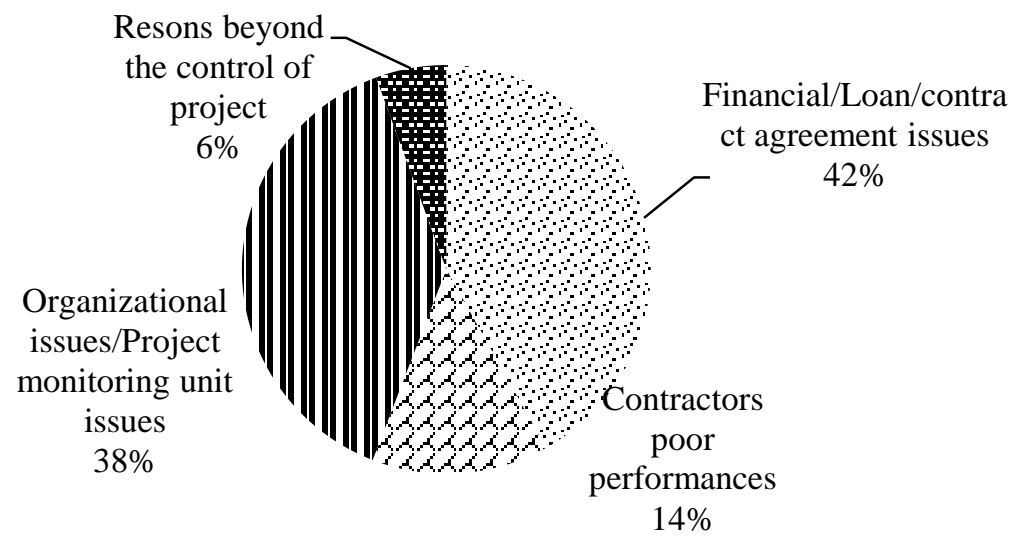

Figure 1: Implementation issues of large and Mega scale project

Source: Progress of development projects and programmes as at 31st of March 2019 (DPMM) 
Kulathunga L.C.M.K., Wanigasekara W.A.D.K.J., Mendis M.O.S., Wayamba Journal Management 12 (2)

\begin{tabular}{|l|l|l|l|}
\hline \hline $\begin{array}{l}\text { Core job } \\
\text { detention } \\
\text { Skill verity } \\
\text { Task Identity } \\
\text { Task Significance } \\
\begin{array}{l}\text { Autonomy } \\
\text { Feedback }\end{array}\end{array}$ & $\begin{array}{l}\text { Critical } \\
\text { Psychological status } \\
\text { Experienced } \\
\text { meaningfulness of the } \\
\text { work }\end{array}$ & $\begin{array}{l}\text { Personal work } \\
\text { outcome } \\
\text { Motivation } \\
\text { Experienced } \\
\text { responsibility for } \\
\text { outcomes of the work } \\
\text { Knowledge of the } \\
\text { actual results of the } \\
\text { work activities }\end{array}$ \\
\hline
\end{tabular}

Figure 2: Job Characteristics Model of Work Motivation

Source: Hackman \& Oldham (1976)

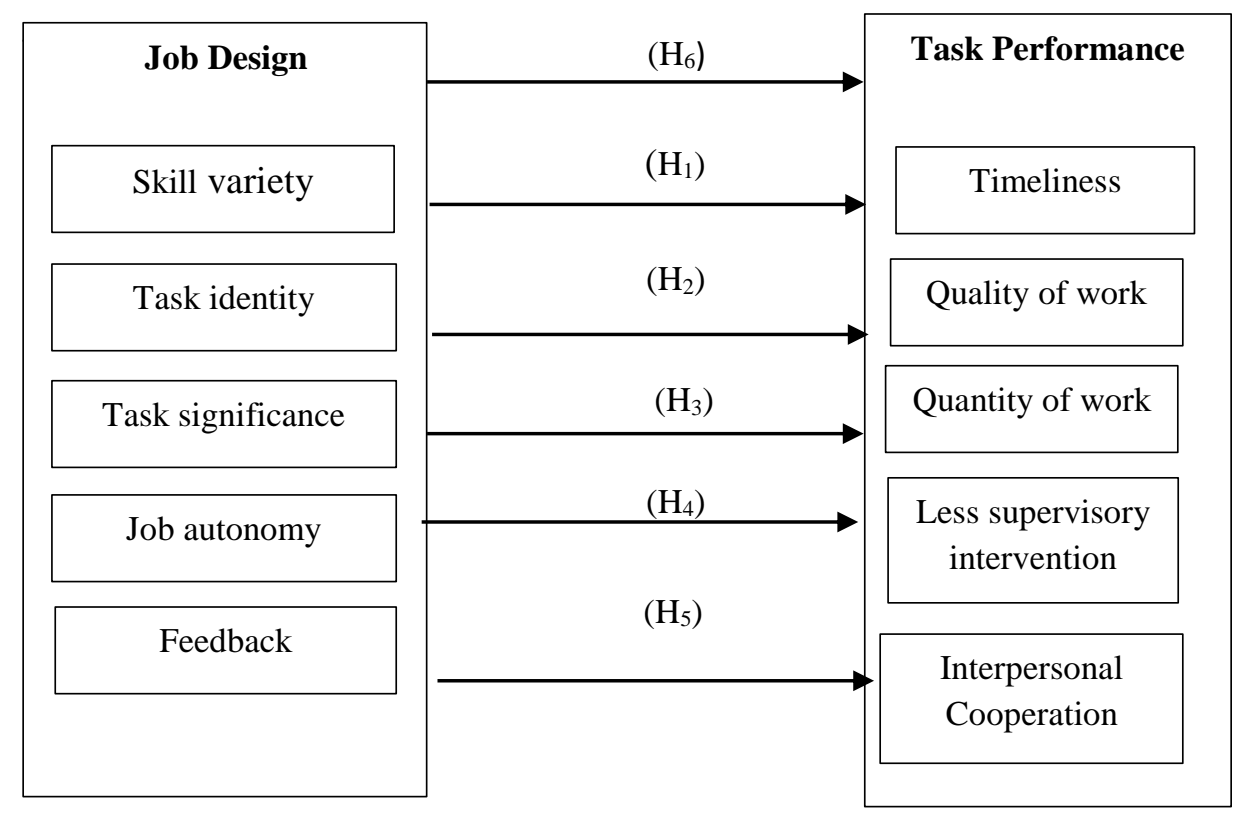

Figure 3: Conceptual Framework

Source: Compiled by the authors 


\section{REFERENCES}

Ali, N. \& Rehman, Z.M. (2014). "Impact of job design on employee performance mediation role of Job Satisfaction : A Study of FMCG's Sector in Pakistan',. International Journal of Business and Management, Vol. 9, No. 2.

Ali.H., \&. Aroosiya., (2010). , Impact Of Job Design On Employees' Performance (With Special Reference To School Teachers In The Kalmunai Zone). Colombo, SriLanka: University of Kelaniya, Sri Lanka.

Ambrose, K. G. (2013). 'Skill Variety, Feedback and Employee Performance: A Case of Moi Teaching and Referral Hospital Eldoret'. European Journal of Business and Management, Vol.5, No.19, .

Athukorala, P. Ginting, E. Hill, H. Kumar, U. (2017). The Sri Lankan Economy: Charting a New Course. http://dx.doi.org/10.22617/T CS178786-2

\footnotetext{
Bacha, E. (2014), "The relationship between transformational leadership, task performance and job characteristics", Journal of Management Development, Vol. 33 No. 4, pp. 410-420. https://doi.org/10.1108/JMD02-2013-0025
}

Bassey, M. (2002), "Motivation and work: investigation and analysis of motivational factors at work", available at: www.ep.liu.se/exjobb/eki/200 2/fek/009/

Benjamin, L.M., (2012), Nonprofit Organizations and Outcome Measurement: From Tracking Program Activities to Focusing on Frontline Work., https://doi.org/10.1177\%2F1 098214012440496.

Boxall, P. Purcell, J. Wright, P.M. (2008). Human Resource Management: Scope, Analysis, and Significance. The Oxford Handbook of Human Resource Management. Doi:10.1093/oxfordhb/97801 99547029.003.0001

Buchanan, D. (1979). The Development of Job Design Theories and Techniques, . New York. : Praeger Publishers.

Campbell, J. (1990). Modeling the performance prediction problem in industrial and organizational psychology. . In Handbook of Industrial and Organizational Psychology (pp. 687-732).

Choge, P. J. (2014). Effects of Task Identity on Employee Motivation: The International 
Kulathunga L.C.M.K., Wanigasekara W.A.D.K.J., Mendis M.O.S., Wayamba Journal Management 12 (2)

Institute for Science, Technology and Education (IISTE). European Journal of Business and Management.

Claessens, B. J. C., van Eerde, W., Rutte, C. G., \& Roe, R. A. (2004). Planning behavior and perceived control of time at work. Journal of Organizational Behavior, 25, 937-950. doi:10.1002/job.292

Davidescu, A. A., Apostu, S. A., Paul, A., Casuneanu, I., (2020). Work Flexibility, Job Satisfaction, and Job Performance among Romanian Employees. Implications for Sustainable Human Resource Management. Sustainability, 12(15), doi:10.3390/su12156086

Davis, L., (2005). Developments in job design. In L. Davis, Personal goals and work design. Wiley,London: P.B.Warr(Ed.).

Demerouti, E. (2006). Job characteristics, Flow and Performance: Moderating role conscientiousness. Journal of occupational Health Psychology, 266280.

Feldman, D. C., Thomas, W. H., (2012). The effects of organizational and community embeddedness on work-to-family and family-to-work conflict. Journal of Applied
Psychology, 97(6), 12331251.

https://doi.org/10.1037/a00 $\underline{29089}$

Feldman, M.S. \& Pentland, B.T. (2003). Reconceptualizing Organizational Routines as a Source of Flexibility and Change. Administrative Science Quarterly, 48 (1), 94-118.

Fiedler, F. (1997). Situational controland a dynamic theory of leadership, classical,contemporary and critical approaches. Oxford: Oxford University Press.

Gallantly, I.R., \& Irving, P.G., (2001), Personality, Autonomy, and Contextual Performance of Managers., Journal of Human performance., 14,03., 231245 .,

https://doi.org/10.1207/S153 27043HUP1403_2

Garg, P. and Rastogi, R. (2005). New Model of Job Design: Motivating employees' performance. Journal of Management Development, 25(6), 572-587.

George, J. \&. Zhou., (2001). When job dissatisfaction leads to Creativity : Encouraging the Expression of Voice . Acadamy of Mangement journal, 682-699.

Ghosh, P. C. (2015). Exploring the moderating role of context satisfaction between job 
Kulathunga L.C.M.K., Wanigasekara W.A.D.K.J., Mendis M.O.S., Wayamba Journal Management 12 (2)

characteristics and turnover intention of employees of Indian public sector bank. Journal of Management Development Vol 34, 10191030.

Gomez, M.D. (2007). Managing Human Resources. USA: Pearson Education $6^{\text {th }}$ Edition.

Grant, A. M., (2010). Putting job design in context: Introduction to the special issue. Journal of Organizational Behavior, 31, 145- 157.

Hackman, J. R., \& Oldham, R. G. (1976). Motivation through the design of work: test of a theory. In J. R. Hackman, Organizational Behavior and Human Performance (pp. 16, 250-79).

Hassan, N.R. (2014) "Value of IS Research: Is there a Crisis?" Communications of the Association for Information Systems, 34(41), pp. 801816.

Hauff, S. and Richter, N. (2015), "Power distance and its moderating role in the relationship between situational job characteristics and job satisfaction: An empirical analysis using different cultural measures", Cross Cultural Management: An International Journal, Vol. 22 No. 1, pp.68-89.

\section{https://doi.org/10.1108/CC} M-11-2013-0164

Herzberg, F. (1976). Motivationhygiene profiles pinpointing what alis the organization.

Herzberg, F. (1966). One more time: How do you motivate employees? . Harvard Business Review, 48, 53-62.

Hirschfeld, R. S. (2002). Jobcontent perceptions performance - reward expectancies, and absenteeism along lowage public - sector clerical employees. Journal of Business and Psychology, 553-564.

Khalid, K. \& Nawab, S. (2018), Employee Participation and Employee: Retention in View of Compensation. SAGE Open, 8(4), doi: $10.1177 / 21582440188100$ 67

Krasman, J. (2012), "Putting feedback-seeking into 'context': job characteristics and feedback-seeking behavior", Personnel Review, Vol. 42 No. 1, pp. 50-66.

Langfred, C. W., \& Moye, N. A. (2004). Effects of Task Autonomy on Performance: An Extended Model Considering Motivational, Informational, and Structural Mechanisms. Journal of Applied Psychology, 89(6), 934-945. 
https://doi.org/10.1037/0021$\underline{9010.89 .6 .934}$

Mawoli, M.A. and Babandako, A.Y. (2011). An Evaluation of Staff Motivation, Dissatisfaction and Job Performance in an Academic Setting. Australian Journal of Business and Management Research, 1, 1-13.

Morgeson, F. P.-K. (2005). The importance of job autonomy, cognitive ability, and jobrelated skill for predicting role breadth and job performance. Journal of Applied Psychology, 399-406.

Morris, M.G. and Venkatesh, V. (2010) Job Characteristics and Job Satisfaction: Understanding the Role of Enterprise Resource Planning System Implementation. MIS Quarterly, 34, 143-161.

Motowidlo, B., (1993). Expanding the criterion domain to include elements of contextual performance. In Personnel Selection in Organizations. In W. C. Borman. San Francisco.

Oldham, G.R. and Cummings, A. (1996) Employee Creativity: Personal and Contextual Factors at Work. Academy of Management Journal, 39, 607-634.

Opatha, H. (2009). Human Resource Management,
Personnel. SriLanka: 1st Ed., Author Publication.

Organ, D. W., (1988). Organizational citizenship behavior: The good soldier syndrome. Lexington Books/D. C. Heath and Com.

Orpen, C. (1979). The reactions of western and tribal Black workers to job characteristics. International Review of Applied Psychology, 28(2),117-125.

Rentsch J.R. and Steel R.P. 2003. What does unit-level absence mean?: Issues for unit-level absence research. Human Resource Management Review, 13: 185-202.

Rush, H. (1971). Job design for motivation :Experiments in job enlargement and job enrichment. Conference Board

Sulea, C. M. (2012). Work engagement as mediator between job characteristics and positive and negative extra-roleextra-role

behaviours. Career Development International, 188-207.

Tierney, P. \&. Farmer., (2002). Creative self -efficacy:Its potential antecedents and relationships to creative performance. Acadamy of Mangement journal, 11371148. 
Kulathunga L.C.M.K., Wanigasekara W.A.D.K.J., Mendis M.O.S., Wayamba Journal Management 12 (2)

Uruthirapathy, A \& Grant, G. (2015) "The Influence of Job Characteristics on IT and Non-IT Job Occupants Turnover Intentions" Journal of Management Development , Vol.34, (6), $715-728$.

Viswesvarn, C. \&. (2000). Perspectives on models of job performance. International
Journal of selection and Assessment, 216-226.

Zhu M, Gao L, Guo Z, Li Y, Wang D, Wang J, Wang C. (2007) Globally predicting protein functions based on coexpressed protein-protein interaction networks and ontology taxonomy similarities. Gene 391(12):113 